DOI: $10.21802 /$ artm.2020.1.13.170.

УДК $614+316.422$

\title{
ТЕОРЕТИКО-ПРАВОВІ АСПЕКТИ РЕФОРМУВАННЯ СИСТЕМИ ОХОРОНИ ЗДОРОВ'Я
}

\author{
І.К. Чурпій ${ }^{1}$, І.В. Мельник ${ }^{2}$, Н.В. Чурпій ${ }^{3}$ \\ Івано-Франківський національний медичний університет, \\ ${ }^{1}$ кафедра фізичної реабілітації, ерготерапії з курсом фізичного виховання, \\ ORCID ID: 0000-0003-1735-9418, e-mail: ch.igor.if@gmail.com, \\ ${ }^{2}$ кафедра хірургії стоматологічного факультету, м. Івано-Франківськ, Україна \\ ORCID ID: 0000-0002-2585-6134, e-mail: imelnik_64@ukr.net \\ ${ }^{3}$ Клініка репродуктивної медицини «Екстрамед», м. Івано-Франківськ, Украӥна \\ ORCID ID: 0000-0002-1997-9592, e-mail:churpiynata@gmail.com
}

Резюме. В останні роки система охорони здоров'я в Україні зазнає постійних змін та модифікацій. Методом спроб та помилок уряд України намагається вибрати найбільш оптимальну систему надання медичних послуг для населення.

Україна одна з багатьох країн, що розвивається на просторах пострадянського простору, і більшість ії галузей перебувають у стадії занепаду. Медичний сектор - не виняток.

У цій статті було проаналізовано основні теоретико-правові аспекти реформування системи охорони здоров'я, їхню рентабельність для населення України, їхню ефективність та ресурсні затрати.

Покращення поінформованості населення у юридичних аспектах новітніх реформ, які діють або ще готуються до вступу в дію, найближчим часом дозволить людям чіткіше розуміти, яких саме змін вони прагнуть, і коригувати роботу уряду.

Зміни кожної країни починаються з кожного жителя цієї країни. I коли кожен громадянин поважатиме себе, своє здоров'я та лікарську працю - саме тоді почнуться справжні зміни.

Сучасна медична установа має відповідати світовим трендам і забезпечувати якість надання медичних послуг шляхом впровадження вимог міжнародних стандартів, зокрема, системи менеджменту якості відповідно до міжнародного стандарту ISO 9001: 2008 з подальшою сертифікацією.

Ключові слова: система охорони здоров'я, медичні технології, медичне страхування.

Вступ. Запорукою міцної держави є здорова нація. Тому в кожній країні в центрі уваги перебувають питання медицини. Що стосується вітчизняної системи охорони здоров'я, то вона потребує суттєвого реформування та особливої участі держави у цьому, оскільки характеризується низкою проблем. Ця тематика для кожного українця $є$ дуже актуальною, адже рівень надання медичних послуг $€$ вкрай неякісним.

Вітчизняна політика держави в галузі охорони здоров'я - це система заходів та загальноприйнятих дій держави, реалізація яких має на меті забезпечити зміцнення психологічного, фізичного та соціального благополуччя як кожної людини, так i всього суспільства, враховуючи потреби як сучасних, так і майбутніх поколінь 3 метою збереження генофонду української нації [1].

В основі сучасної моделі державної політики України у сфері охорони здоров'я повинно бути розуміння того, що здоров'я людини - це соціально економічна цінність, а пріоритет держави - це реалізація іiі дій для забезпечення здоров'я кожної людини. Держава здійснює свою політику в сфері охорони здоров'я відповідно до нормативно-правової бази, в основі якої лежить Конституція України. Головна мета держави при здійсненні такої політики забезпечити громадян доступною та ефективною медициною [2].
Важливість охорони здоров'я у житті кожної держави неможливо переоцінити. В цей час сфера охорони здоров'я виконує покладені на неї функції насамперед за рахунок фінансування i належного державного регулювання. В основі останнього лежить нормативно-правова база, що визначає правове положення органів, установ і посадових осіб у галузі охорони здоров'я. Саме за рахунок управління система організації медичної допомоги набуває ефективності, що сприяє найповнішій реалізації покладених завдань. Слід зазначити, що на початку періоду демократичних перетворень у нашій державі стала помітною тенденція до зниження ролі і значення державного управління в охороні здоров'я громадян. Поява разом 3 державними і комунальними також i приватних лікувальних установ, поява добровільного медичного страхування сприяли формуванню точки зору про непотрібність управлінських структур. Вважалося, що аналогічно 3 іншими сферами життя, ринок у медицині здатний ефективно управляти наданням медичної допомоги і вирішувати проблеми, які виникають. Проте реальні події показали, що таке положення не є оптимальним. Вплив держави, що реалізовується за допомогою органів управління охорони здоров'я, $є$ необхідною умовою функціонування медицини в країні. Для здійснення державного управління у сфері охорони здоров'я громадян використовуються правові, 
адміністративні, економічні, соціально-психологічні методи.

Охорона здоров'я - це система заходів, спрямованих на забезпечення збереження і розвитку фізіологічних і психологічних функцій, оптимальної працездатності та соціальної активності людини при максимальній біологічно можливій індивідуальній тривалості життя [ 3]. Україні є:

Основними принципами охорони здоров'я в

- визнання охорони здоров'я пріоритетним напрямом діяльності суспільства і держави, одним 3 головних чинників виживання та розвитку народу України;

- дотримання прав і свобод людини і громадянина в галузі охорони здоров'я та забезпечення пов'язаних 3 ними державних гарантій;

- гуманістична спрямованість, забезпечення пріоритету загальнолюдських цінностей над класовими, національними, груповими або індивідуальними інтересами, підвищений медикосоціальний захист найбільш вразливих верств населення;

- рівноправність громадян, демократизм i загальнодоступність медичної допомоги та інших послуг у галузі охорони здоров'я;

- відповідність завданням i рівню соціальноекономічного та культурного розвитку суспільства, наукова обгрунтованість, матеріально-технічна і фінансова забезпеченість; орієнтація на сучасні стандарти здоров'я та медичної допомоги, поєднання вітчизняних традицій i досягнень із світовим досвідом у галузі охорони здоров'я;

- попереджувально-профілактичний характер, комплексний соціальний, екологічний та медичний підхід до охорони здоров'я;

- багатоукладність економіки охорони здоров'я i багатоканальність ¥іі фінансування, поєднання державних гарантій 3 демонополізацією та заохоченням підприємництва і конкуренції;

- децентралізація державного управління, розвиток самоврядування закладів та самостійності працівників охорони здоров'я на правовій і договірній основі (Основи законодавства України про охорону здоров’я від 19 листопада 1992 року № 2801-XII).

Значну роль у практичній реалізації цих принципів відіграє система управління охорони здоров'я, яка складається з:

- Міністерства охорони здоров’я України;

- місцевих державних адміністрацій та органів місцевого самоврядування;

- центральних органів виконавчої влади, яким підпорядковані заклади охорони здоров'я;

- Національної академії медичних наук України.

Важливе місце у процесі управління у сфері охорони здоров'я відіграють урядові органи державного управління у складі Міністерства охорони здоров'я України. Йдеться про:

a) Державну службу лікарських засобів i виробів медичного призначення; наркотиками.
Місцеві державні адміністрації та органи місцевого самоврядування здійснюють регулювання у сфері охорони здоров'я за рахунок наявності у їх структурі обласних та районних управлінь (відділів) охорони здоров'я та відповідних структур виконавчих комітетів рад. Слід підкреслити, що органи місцевого самоврядування здійснюють керівництво діяльністю комунальних закладів охорони здоров'я.

Основними завданнями управлінь охорони здоров’я у складі місцевих органів виконавчої влади $\epsilon:$

- забезпечення реалізації державної політики в галузі охорони здоров'я;

- прогнозування розвитку мережі закладів охорони здоров'я для нормативного забезпечення населення медико-санітарною допомогою;

- здійснення заходів, спрямованих на запобігання інфекційним захворюванням, епідеміям і на їx ліквідацію;

- організація надання медико-санітарної допомоги населенню, роботи органів медико-соціальної експертизи, закладів судово-медичної та судовопсихіатричної експертизи;

- забезпечення виконання актів законодавства в галузі охорони здоров'я, державних стандартів, критеріїв та вимог, спрямованих на збереження навколишнього природного середовища і санітарноепідемічного благополуччя населення, a також додержання нормативів професійної діяльності в галузі охорони здоров'я, вимог Державної фармакопеї, стандартів медичного обслуговування, медичних матеріалів i технологій (Постанова Кабінету Міністрів України «Про затвердження Типового положення про управління охорони здоров'я обласної, Севастопольської міської державної адміністрації та Головне управління охорони здоров'я Київської міської державної адміністрації» $[2,4]$.

Розглядаючи управління у сфері медичної діяльності в країні, варто згадати про поділ всієї системи охорони здоров'я на три види (державну, комунальну, приватну).

До державної системи охорони здоров'я належать: Міністерство охорони здоров'я України, Академія медичних наук, які в межах своєї компетенції планують i здійснюють заходи 3 реалізації державної політики України, виконання програм у галузі охорони здоров'я та у сфері розвитку медичної науки. До державної системи охорони здоров'я також належать лікувальнопрофілактичні і науково-дослідні установи, освітні установи, фармацевтичні підприємства і організації, аптечні установи, санітарно-профілактичні установи, установи судово-медичної експертизи, служби матеріально-технічного забезпечення, підприємства 3 виробництва медичних препаратів і медичної техніки та інші підприємства, установи та організації, що знаходяться в державній власності і підлеглі органам управління державної системи охорони здоров'я [5].

До комунальної системи охорони здоров'я належать: місцеві органи управління охорони здоров'я, а також лікувально-профілактичні і науково- 
дослідні установи, фармацевтичні підприємства i організації, аптечні установи, освітні установи комунальної власності.

Місцеві органи управління охорони здоров'я несуть відповідальність за санітарно-гігієнічне благополуччя населення, забезпечення доступності населенню гарантованого об'єму медико-соціальної допомоги, розвиток системи охорони здоров'я на підвідомчій території, здійснюють контроль за якістю надання медико-соціальної i лікарської допомоги підприємствами, установами і організаціями державної, комунальної, приватної систем охорони здоров'я, а також особами, що займаються приватною медичною практикою.

До приватної системи охорони здоров'я належать: лікувально-профілактичні і аптечні установи, майно яких знаходиться в приватній власності, а також особи, що займаються приватною медичною практикою і приватною фармацевтичною діяльністю. У приватну систему охорони здоров'я входять лікувально-профілактичні, аптечні, науководослідні установи, освітні установи, що створюються i фінансуються приватними підприємствами, установами i організаціями, суспільними об'єднаннями, а також фізичними особами.

Важливим чинником, на який необхідно звернути увагу, $€$ принципові відмінності між державними i комунальними лікувальними установами 3 одного боку, і приватними 3 іншого. Найбільш важливі 3 них формулюються у вигляді двох положень:

1. Призначення. Державні і комунальні лікувальні установи призначені для надання медичної допомоги громадянам за рахунок коштів, які ці установи отримують 3 бюджетів різних рівнів, інших не заборонених законом надходжень. В той же час приватні лікувальні установи призначені для отримання прибутку. Цей прибуток, як правило, отримується за рахунок надання якісної медичної допомоги. Висока якість необхідна для повноцінної конкуренції 3 безкоштовними державними i комунальними лікувальними установами.

2. Власність. Державні і комунальні лікувальні установи знаходяться у власності держави і місцевих утворень, а приватні - в приватній власності.

Із введенням ринкових відносин в охороні здоров’я питання якості медичної допомоги стає все більш актуальним. Будь-яка медична послуга може знайти свій сегмент ринку тільки в тому випадку, якщо буде виконана на досить високому рівні [6].

Питання якості надання медичних послуг $\epsilon$ одним з найбільш важливих у сучасній охороні здоров'я. 3 метою впливу на рівень якості медичних послуг розроблено і впроваджено такі механізми:

- ліцензування діяльності 3 медичної практики та контроль за виконанням ліцензійних умов;

- акредитація закладів охорони здоров'я;

- система стандартів у сфері охорони здоров'я;

- контроль якості медичних послуг;

- сертифікація медичних установ відповідно до стандарту ISO 9001: 2008.

Використано метод системного підходу в менеджменті якості надання медичних послуг.
Стандарт ISO 9001: 2008 «Системи управління якістю, вимоги» є базовим для розробки системи менеджменту якості у клініці для iï сертифікації [71]. Принципи менеджменту якості, встановлені в ISO 9000 та ISO 9001, враховані в стандарті ICO 9001. Стандарт ICO 9001 базується на двох методологічних аспектах: 1) процесному підході та орієнтації на споживача (пацієнта) і 2) задоволенні очікувань споживачів (пацієнтів). Внутрішня документація 3 якості описує взаємодії процесів і послуг у відповідних протоколах, положеннях, інструкціях і т. д., а також передбачає обов'язковий моніторинг і контроль усіх процесів 3 аналізом отриманих результатів, метою якого є постійне поліпшення якості й вибору оптимальних та ефективних методик надання послуг [7].

Концепція якості надання медичних послуг $є$ глобальною і різнобічною. Експерти, зазвичай, розрізняють кілька основних характеристик якості:

1. Професійна компетенція: рівень навичок $\mathrm{i}$ вмінь, які реалізуються в процесі діяльності людей, що надають медичне обслуговування, діяльності керівництва та обслуговуючого персоналу.

2. Доступність медичної допомоги: ступінь, на якому медична допомога може безперешкодно надаватися незалежно від географічних, економічних, соціальних, культурних, організаційних чи мовних факторів.

3. Результативність: ступінь, на якому лікування пацієнта сприяє поліпшенню його стану або бажаному результату.

4. Міжособистісні відносини: якість взаємодії між постачальниками послуг та споживачами, а саме: між керівництвом і персоналом, медичними працівниками та пацієнтами.

5. Ефективність: постійно існуюча напруга між потребою в обслуговуванні і наявними ресурсами надання допомоги. Проект забезпечення якості визначає ефективність як надання оптимальної медичної допомоги населенню, тобто оптимальна кількість медичної допомоги досяжна при використовуваних ресурсах.

6. Безперервність: ступінь, на якому пацієнт отримує необхідне йому медичне обслуговування без перерв, зупинок або зайвих повторень діагнозу або лікування.

7. Безпека: ступінь, на якому система медичної допомоги знижує ризик пошкоджень, інфікування, шкідливих побічних явищ або іншого збитку, що наноситься в процесі надання медичної допомоги.

8. Комфортність: характеристика медичного обслуговування, яка безпосередньо не відноситься до клінічної ефективності, але може позитивно вплинути на задоволеність пацієнта якістю обслуговування. Комфортність визначається як зовнішній вигляд i чистота всіх використовуваних приміщень, обладнання та персоналу, а також заходи, які вживаються для забезпечення комфорту і зручності пацієнта.

Відповідно до ISO 9001, діяльність щодо забезпечення якості медичної установи має бути спрямована як на клінічний, так і на організаційний аспект надання медичних послуг.

Впровадження стандарту ISO 9001 і подаль- 
ша сертифікація системи якості дають змогу виявити неефективні ланки у діяльності клініки, підвищити ефективність використання ресурсів, уникнути як дублювання робіт, так і «оголення» окремих ділянок, документувати всі виробничі операції, встановити відповідальність за кожну з них, провести структуризацію виробничих процесів і вибудувати чіткі технологічні схеми, а найголовніше - істотно підвищити якість медичних послуг. Крім того, впровадження та сертифікація системи менеджменту якості підвищує престиж самого лікувального закладу.

Впровадження ISO 9001 і подальша сертифікація системи управління якістю у клініці - етап структурно-функціонального розвитку, що забезпечує бездоганний сервіс і зручність, насамперед для пацієнта. Така сертифікація передбачає постійну адаптацію менеджменту до нових умов, як внутрішніх, так і зовнішніх. Зростає значення нової системи менеджменту якості і в умовах страхової медицини, коли страхові компанії, які оплачують лікування, потребують гарантії високого рівня обслуговування для своїх клієнтів.

Головною вимогою Міжнародної організації зі стандартизації є стабільне проведення роботи щодо поліпшення якості виробленої продукції або ж послуг, що надаються. Контроль за відповідністю клініки вимогам ISO 9001: 2008 проводиться динамічно, після первинної сертифікації укладають контракт з установою на три роки, а потім кожні 12 місяців спеціальна міжнародна аудиторська група повторно проводить оцінку системи менеджменту.

За інформацією Міжнародної організації зі стандартизації [7], у 2015 р. всього у світі видано 1 111698 сертифікатів ISO 9001, з них 1935 закладам охорони здоров'я; по країнах: у США - 23 950, Великій Британії - 19 353, Російській Федерації - 12 880, Україні - 521.

Висновки. Сучасна медична установа має відповідати світовим трендам і забезпечувати якість надання медичних послуг шляхом впровадження вимог міжнародних стандартів, зокрема, системи менеджменту якості відповідно до міжнародного стандарту ISO 9001: 2008 з подальшою сертифікаці$€ ю$.

\section{References:}

1. Artamonova NO. Patent Document Analysis as an Innovation Management Tool (Part One) [Text] Visn. Book. chambers. 2015; 10:34-36.

2. Bolyukh MA. Analysis of financial and economic activities of budgetary institutions: a textbook [Text] K.: KNEU, 2019. P.342.

3. Togunov IA. Doctor and patient of medical services [Electronic resource] Vladimir Oblast Compulsory Health Insurance Fund. Access mode: www.marketing.spb.ru.

4. Artamonova NO. State of information support of medical innovations [Text] Bibl. hanging. 2018; 5:1417.

5. Proceedings of the EU Project "Promoting the Development of Secondary Medical Assistance in Ukraine" [Electronic resource]. - Access mode: http:
//www.eu-shc.com.ua/catalogs/5/35/47/516/1AN Non Profit Ent Register 150209 Ukr final.doc.

6. Orel VE. Analysis of problems of innovative development of medicine in Ukraine [Text] VE Eagle. Science and science. 2019; 3:127-129.

7. Hait LB. Investigation of problems of introduction of quality management system of medical services delivery: modern theoretical approaches. The theory and practice of public administration [Electronic resource]. 2018; 2(29). Access mode: http://www.kbuapa.kharkov.ua/e-book/tpdu/2018-2/ $\operatorname{doc} / 1 / 15 . p d f$

\section{УДК $614+316.422$ \\ ТЕОРЕТИКО-ПРАВОВЫЕ АСПЕКТЫ РЕФОРМИРОВАНИЯ СИСТЕМЫ ЗДРАВООХРАНЕНИЯ}

\author{
И.К. Чурпий, И.В. Мельныюк , Н.В. Чурпий
}

Ивано-Франковский нацииональный медицинский университет,

${ }^{1}$ кафедра физической реабилитации, эрготерапии с курсом физического воспитания,

ORCID ID: 0000-0003-1735-9418,

e-mail:ch.igorif@gmail.com

${ }^{2}$ кафедра хирургии стоматологического факультета,

2. Ивано-Франковск, Украина

ORCID ID: 0000-0002-2585-6134,

e-mail: imelnik_64@ukr.net

${ }^{3}$ Клиника репродукктивной медиичны «Екстрамед»,

2. Ивано-Франковск, Украина

ORCID ID: 0000-0002-1997-9592,

e-mail:churpiynata@gmail.com

Резюме. Последние годы система здравоохранения в Украине подвергается постоянным изменениям и модификациям. Методом проб и ошибок правительство Украины пытается выбрать наиболее оптимальную систему оказания медицинских услуг для населения.

Украина одна из многих стран, развивающихся на просторах постсоветского пространства, и большинство ее отраслей находятся в стадии упадка. Медицинский сектор не является исключением. В этой статье были проанализированы основные теоретико-правовые аспекты реформирования системы здравоохранения, их рентабельность для населения Украины, их эффективность и ресурсные затраты.

Улучшение информированности населения в юридических аспектах новейших реформ, которые действуют или еще готовятся к вступлению в действие, в ближайшее время позволит людям более четко понимать, какие именно изменения они хотят, и корректировать работу правительства.

Изменения каждой страны начинаются с каждого жителя этой страны. И когда каждый гражданин будет уважать себя, свое здоровье и врачебный труд - именно тогда начнутся настоящие изменения. 
Современное медицинское учреждение должно соответствовать мировым трендам и обеспечивать качество предоставления медицинских услуг путем внедрения требований международных стандартов, в частности, системы менеджмента качества в соответствии с международным стандартом ISO 9001: 2008 с последующей сертификацией.

Ключевые слова: система здравоохранения, медицинские технологии, медицинское страхование.

\section{UDC $614+316.422$ \\ THEORETICAL AND LEGAL ASPECTS OF HEALTH CARE REFORM}

\author{
I.K. Churpiy ${ }^{1}$, I.V. Melnyk ${ }^{2}$, N.V. Churpiy ${ }^{3}$ \\ Ivano-Frankivsk National Medical University, \\ ${ }^{I}$ department of physical rehabilitation, ergotherapy \\ with a course of physical education, \\ ORCID ID: 0000-0003-1735-9418, \\ e-mail: ch.igor.if@gmail.com, \\ ${ }^{2}$ department of Surgery, Dental Faculty, Ivano-Frankivsk, \\ Ukraine \\ ORCID ID: 0000-0002-2585-6134, \\ e-mail:imelnik_64@ukr.net \\ ${ }^{3}$ Private clinic of reproductive health «Extramed», \\ Ivano-Frankivsk, Ukraine \\ ORCID ID: 0000-0002-1997-9592, \\ e-mail:churpiynata@gmail.com
}

Abstract. In recent years, the healthcare system in Ukraine has had constant changes and modifications. Through trials and errors, the government of Ukraine is trying to choose the most optimal system of medical services for the population.

Ukraine is one of many developing countries in the post-Soviet space and most industries are in decline. The medical sector is no exception. This article analyzes the main theoretical and legal aspects of health care reform, their profitability for the Ukrainian population, their efficiency and resource costs.
Improving public awareness of the legal aspects of the latest reforms, which are in place or are about to come into action in the near future, will allow people to more clearly understand what changes they are seeking and adjust the work of the government.

Changes to each country start with every resident of that country. And when every citizen respects himself, his health and medical work - that is when the real changes will begin.

The current model of Ukraine's public health policy should be based on the understanding that human health is a socio-economic value, and the priority of the state is the implementation of its actions to ensure the health of each person. The main goal of the state in implementing such a policy is to provide citizens with affordable and effective medicine.

The quality of health care delivery is one of the most important issues in modern health care. The systematic approach to quality management of health care delivery is used. The quality management principles set out in ISO 9000 and ISO 9001 are based on ISO 9001. ISO 9001 standard on two methodological aspects: 1) process approach and consumer (patient) orientation and 2) customer (patient) expectations.

According to ISO 9001, the quality assurance activities of the healthcare facility should be focused on clinical, and the organizational aspect of health care delivery. The introduction of ISO 9001 and the subsequent certification of the quality system make it possible to identify ineffective links in the clinic's activities, increase the efficiency of use of resources, avoid both duplication of work and "exposing" individual sites, document all production operations, establish responsibility for each of them, carry out the structuring of production processes and build clear technological schemes, and most importantly - significantly improve the quality of medical services.

In addition, the introduction and certification of a quality management system enhances the prestige of the hospital.

Keywords: health care system, healthcare technology, health insurance.

Саття надійшла в редакцію 09.03.2020 р. 